Avoimesti luettavissa osoitteessa http://journal.fi/ainedidaktiikka

ainedidaktiikka

\title{
Alakoulun oppilaiden kokemuksia ratkaisukeskeisen ilmastokasvatuksen toteutuksesta: havaintoja oppimisesta ja tunteista
}

\author{
Ilkka Ratinen ja Reetta Pahtaja
}

Kasvatustieteiden tiedekunta, Lapin yliopisto

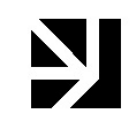

Ratkaisukeskeisen ilmastokasvatuksen tavoitteena on oppia tietoja ja taitoja, joiden avulla opitaan vähentämään ilmastopäästöjä ja sopeutumaan ilmastonmuutokseen parhaalla mahdollisella tavalla. Ilmastonmuutoksen hillintä ja siihen sopeutuminen vaatii onnistuessaan myös tunteiden huomioon ottamista. Ilmastokasvatuksessa toivon ylläpitäminen on mahdollista merkityksiä luovien toimintastrategioiden avulla. Oleellista on, että oppija pohtii tekojensa merkityksellisyyttä, minkä avulla voidaan välttää toiveajattelua. Alakoulussa ilmastokasvatus perustuu tutkivaan oppimiseen ja dialogiseen, oppijan arkikäsityksen huomioon ottavaan vuorovaikutukseen. Vuorovaikutuksellinen opetus sitouttaa oppijat opetukseen. Artikkelissa pohditaan ilmastokasvatuksen toteutumista alakoulun oppilaiden näkökulmasta. Tutkimuksen aineisto kerättiin avoimella kyselylomakkeella kahdeksasta alakoulun luokasta, viidestä eri koulusta. Tutkimusaineisto koostuu 152 oppilaan vastauksista. Vastaukset analysoitiin laadullisella sisällönanalyysillä ja teemoitettiin fenomenografisesti eri käsitekategorioihin. Käsitekategoriat muodostuivat neljästä teemasta: 1) Uuden oppimisesta, 2) kiinnostuksen lisääntymisestä, 3) ilmastonmuntokseen liittyvästä toivosta ja 4) ilmastonmuutokseen liittyvästä surusta.

Ratkaisukeskeinen ilmastokasvatus, toivo, alakoulu

Lähetetty: 24.4.2020

Hyväksytty: 23.9.2020

Vastuukirjoittaja: ilkka.ratinen@ulapland.fi

DOI: $10.23988 /$ ad.91575 


\section{Johdanto}

Ilmastokasvatus on yksi ympäristökasvatuksen osa-alue, jossa keskeistä on ilmastonmuutoksen syvällisen ymmärryksen lisäksi käyttäytymisen ja toiminnan muutokset (Lehtonen \& Cantell, 2015). Ilmastokasvatuksessa, kuten ympäristökasvatuksessa kokonaisuudessaan, ei olla onnistuttu kovinkaan hyvin saamaan ihmisiä aktivoitumaan laajasti ilmastoongelmien ratkaisijoina. Alan Reid (2019) avaa lukuisiin tutkimuksiin viitaten, että ilmastokasvatuksella voidaan edistää kansalaisten käyttäytymistä, joka johtaa ilmastonmuutokseen hillintään ja siihen sopeutumiseen. On kuitenkin varsin vähän konkreettisia oppimismalleja, kuinka hillintää ja sopeutumista voisi oppia ratkaisukeskeisesti.

Suomen ilmastopaneelin määritelmän mukaan ratkaisukeskeinen ilmastokasvatus on "ympäristö- ja kestävän kehityksen kasvatuksen osaalue, jossa oppija ohjataan kestävään elämäntapaan ja etsitään ratkaisukeskeisiä sekä sosiaalisesti hyväksyttäviä keinoja ilmastopäästöjen vähentämiseen, hiilinielujen lisäämiseen ja ilmastonmuutokseen sopeutumiseen" (Ratinen, Kinni, Muotka \& Sarivaara, 2019). Tavoitteena on siis ilmastonmuutoksen hillintä- ja sopeutumistaitojen oppiminen. Ilmastokasvatuksen ratkaisukeskeisessä prosessimallissa korostuu ennalta määrätyn systeemin sisälle asetetut hillintä- ja sopeutumistavoitteet, joiden toteutumista arvioidaan ja reflektoidaan myös systeemin ulkopuolelle. Ratkaisukeskeisessä ilmastokasvatuksessa tavoitteellisella toimella tarkoitetaan sitä, että toteutettu toimi aidosti vähentää jonkin suoritteen ilmastovaikutusta tai sopeutuminen perustuu tutkittuun tietoon (Ratinen ym., 2019, ss. 32-33). Prosessimallin mukainen opetus tapahtuu niin sanottujen ilmastokasvatuksen ikkunoiden kautta ja tämä artikkeli liittyy juuri niihin. Onnistunut ratkaisukeskeinen ilmastokasvatus sisältää ilmastonmuutokseen liittyvän tiedon ja tunteet, jotka toimivat pohjana ilmastomyönteiselle toiminnalle sekä arvojen ja asenteiden muodostumiselle lapsuudesta lähtien. Ratkaisukeskeinen ilmastokasvatus perustuu sosiokulttuuriseen oppimiskäsitykseen, jossa opettajan tulee kuunnella oppijoita ja ottaa huomioon myös heidän tunteensa ilmastonmuutosta kohtaan (Ratinen, 2016). Keskustelemalla ja käsittelemällä oppilaiden huolia tietopohjaista materiaalia hyödyntäen voidaan siirtyä kriittisyydestä kohti ratkaisukeskeistä ilmastokasvatusta (Ojala, 2015).

Ilmastonmuutos on haastava teema ymmärtää. Käsiteltäessä ilmastonmuutokseen liittyvää tietoa, käsitteitä ja syy-seuraussuhteita opetuksessa on tärkeää ottaa huomioon oppijoiden ikä. Alakoulussa ratkaisukeskeinen ilmastokasvatus pohjautuu ilmastonmuutoksen luonnontieteellisiin perusteisiin. Shepardsonin, Niyogin, Roychoudhuryn ja Hirschin (2012) mukaan ilmastokasvatuksessa tulisi käsitellä ainakin ilmastojärjestelmän syitä ja muutoksia, ilmakehää, lumen ja jään määrää, valtameriä, maaperää ja kasvillisuutta sekä vaikutuksia ihmisiin. Alakoulussa ilmastonmuutoksen käsittelyssä ei kuitenkaan ole syytä mennä kovinkaan abstrakteihin molekyylitason ilmiöihin, sillä alakouluikäisillä (pois lukien kuudesluokkalaiset) ei ole vielä tarvittavia käsitteitä, joiden avulla kyseisiä 
ilmiöitä selitetään. Oppilaille kannattaa kertoa ensin, että ihmisten haitalliset ilmastopäästöt eli kasvihuonekaasut lämmittävät ilmakehää (Ratinen, 2016). Tämän jälkeen tulisi miettiä, miten kasvihuonekaasupäästöjä voidaan vähentää.

Viime vuosina oppilaiden tunteiden käsittelyn rooli on kasvanut ilmastokasvatuksessa Suomessa (Pihkala, 2017, a, b, c) ja muualla maailmassa (Chapman, Lickel \& Markowitz, 2017). Tunteiden käsittely tulee ottaa huomioon kaiken ikäisille suunnatussa ratkaisukeskeisessä ilmastokasvatuksessa erityisesti siksi, että sen avulla on mahdollista ratkaista ilmastonmuutokseen liittyviä sukupolvien välisiä ristiriitoja. Tärkeää on, että aikuiset viestivät lapsille ymmärtävänsä kriisin vakavuuden ja siihen liittyvät tunteet (Pihkala, 2017a). Tiedämme, että lukuisat lapset kokevat huolta, pelkoa ja ahdistusta ilmastonmuutoksen vuoksi (Ojala, 2012b; Burke \& Sanson, 2018). Yhdysvaltalaisessa haastattelututkimuksessa todettiin, että 10-12-vuotiaista amerikkalaislapsista $82 \%$ koki merkittäviä pelon, surullisuuden tai suuttumuksen tunteita ympäristöongelmien vuoksi (Strife, 2012). Kasvattajien tulisikin olla tietoisia, että tunteet vaikuttavat lapsiin jo ennen oppimistilanteita. Ympäristösuru on usein ympäristöahdistuksen tai epätoivon ilmentymä, johon tulee kiinnittää kasvatuksessa huomiota. Suru ei kuitenkaan aina ole huono asia ilmastokasvatuksessa, sillä nuorten kokema ympäristösuru voi tarjota yhteistyön rakentamisen mahdollisuuksia sukupolvien väliselle yhteiselle affektiivis-emotionaaliselle pohjalle (Pihkala, 2019b). Saksalaisen psykologin Pekrunin (2016) mukaan tunteet vaikuttavat oppimiseen monella tavalla. Ilmastokasvatuksessa erityisesti tunteiden ääripäät eli toivon ja surun tunteminen vaikuttavat merkittävällä tavalla oppimiseen ja siihen kokevatko he hallitsevansa itselleen tärkeitä toimintoja ja tuloksia.

Onnistuessaan tunnekasvatus voidaan nähdä merkittävässä roolissa osana alakoulun ilmastokasvatusta sekä oppilaan tunnetaitojen että sukupolvien välisten suhteiden kehittymisen kannalta. Lapset ja nuoret ovat vaikuttajia tässä ylisukupolvisessa yhteistyössä. Aarnio-Linnanvuoren (2018) mukaan ympäristövastuullisuuteen kasvamisen kannalta olisi tärkeää keskustella yksilön vaikutusmahdollisuuksista ja ympäristöongelmien ratkaisuista sekä päästä jo alakouluikäisenä harjoittelemaan kyseisiä taitoja. Ajatus sopii myös ylisukupolviseen ilmastokasvatukseen. Alakoulun ilmastokasvatuksessa olisikin tärkeää, että oppilaat saavat aitoja vaikuttamisen kokemuksia, kasvavat näkemään vaikuttamisen tärkeänä kansalaistaitona, sekä oppivat toimimaan omaehtoisesti aktiivisina vaikuttajina yhteisöissään (Muotka \& Kinni, 2019; Sipari, 2016). Tolppanen, Aarnio-Linnanvuori, Cantell ja Lehtonen (2017) kuitenkin toteavat, että myös negatiiviset tunteet tulee ottaa huomioon ilmastokasvatuksen opetuksessa. Ilmastonmuutos herättää syyllisyyden lisäksi ahdistusta, häpeää, torjuntaa ja jopa kieltämistä (Lehtonen \& Välimäki, 2013). Tämä voi osaltaan lisätä negatiivisuutta muutosta kohtaan. Toisaalta negatiiviset tunteet, kuten tuohtumus tai pettymys, voivat toimia tärkeänä toimeenpanijana ilmastotoimiin ryhdyttäessä. Tällöin tunteet tulee pystyä kanavoimaan toiminnaksi osana opetusta. Erityisesti alakoulun ilmastokasvatuksessa negatiivisten tunteiden esiin nousemista ja käsittelyä tulee tukea, jotteivat ne jää vaikuttamaan epätoivotulla tavalla iän vuoksi herkkien oppilaiden suhtautumiseen ilmastotoimia kohtaan. 
Alakoulun ilmastokasvatuksessa pelkkä tieto tai asennekasvatus ei riitä, sillä sellaisenaan se ei johda tavoitteelliseen toimintaan. Degermanin (2016) mukaan asenteet ja tieto ovat kuitenkin yhteydessä toisiinsa: Mitä vakavampana asiana peruskoulunsa päättävät oppilaat pitivät ilmastonmuutosta, sitä enemmän he tutkimuksen mukaan tiesivät aiheesta. Ilmastomyönteiseen käyttäytymiseen kasvaminen vaatii myös arvokasvatusta sekä arvokeskusteluiden läpikäymistä oppilaiden kanssa osana ilmastokasvatusta (Tolppanen ym., 2017). Kuten Tolppanen ja muut (2017) kirjoittavat, ei ilmastonmuutokseen liittyviä ongelmia pystytä kunnolla käsittelemään ilman kriittistä ajattelua. Alakoulussa kriittinen ajattelu tulee ulottaa lapsen arjessa olevien asioiden tarkasteluun, jotta opiskeltava aihe motivoisi oppilasta eikä se näin ollen jäisi etäiseksi tai liian vaikeasti ymmärrettäväksi. Ilmastonmuutoksen etäiseksi jääminen hankaloittaa ilmastokasvatuksen onnistumista. Kuten Degerman (2016) havaitsi, ilmastonmuutos ei koskettanut opiskelijoita, sillä he asuvat turvallisessa osassa maapalloa, Suomessa. Toisaalta voi pohtia, että nuorten ilmastoliikehdintä ja nopeasti muuttuneet sääilmiöt ja epätavalliset vuodenajat ovat vaikuttaneet nuorten asenteisiin ja tunteisiin ilmastonmuutosta kohtaan. Ilmastomyönteiseen käyttäytymiseen kasvamista tukee ilmastomyönteisiä arvoja kantava ryhmä ja siihen samaistuminen. Bambergin, Reesin ja Seebauerin (2015) mukaan ympäristömyönteiseen ryhmään samaistuminen voi vahvistaa yksilön ilmastotoimijuutta. Ilmastonmuutokseen vastaaminen vaatii yhteisöllistä vastuunkantoa, jota voi alakoulussa harjoitella.

Ratkaisukeskeisessä ilmastokasvatuksessa on erityisen tärkeä säilyttää toivon näkökulma, sillä toivottomuus johtaa näköalattomuuteen, eikä viime kädessä auta ilmastonmuutoksen hillinnässä (Li \& Monroe, 2017; Ojala, 2013b; Ojala \& Bengtsson, 2019; Pihkala, 2017b). Li ja Monroe (2017) korostavat, että toivoa ylläpitävien ilmastotoimien yhteydessä on tärkeää tarkoituksenmukainen informaatio, merkitykselliset teot ja usko yhteiskunnan kykyyn tehdä tehokkaita toimia. Toivo liittyy myös positiiviseen ajatteluun. Ojalan ja Bengtssonin (2018) tutkimuksessa positiivisuus vaikutti ongelmakeskeisten ja merkitystä luovien ratkaisumallien kanssa. Toivon avulla yksilö voi säilyttää merkityksellisyyden myös silloin, kun varsinainen optimismi on vaikeaa (Pihkala, 2017c). Myös Värri (2018) painottaa, että kasvatus ja toivo kuuluvat yhteen. Toivon, joka perustuu ilmastonmuutoksen vakavuuden kieltämiseen, on todettu korreloivan negatiivisesti ympäristömyönteisen käytöksen kanssa (Ojala, 2012; Ratinen \& Uusiautti, 2020). Ratkaisukeskeisen ilmastokasvatuksen tulisi rakentua alakoulussa nimenomaan realistisen toivon pohjalle. Rakentava toivo on yhdistetty nuorten sekä nuorten aikuisten ympäristömyönteiseen käytökseen.

Värri (2018) korostaa, että lasten kuuluu saada kokea tulevaisuutensa toiveikkaana, sillä muuten elämä menettää mielekkyytensä ja perustansa. Tulevaisuuteen liittyvää toivoa voidaan tarkastella myös tulevaisuuskasvatuksen avulla, mikä on yksi ilmastokasvatuksen tarkastelukeinoista (Branchetti ym., 2018). Tolppasen ja muiden (2017) mukaan tulevaisuusskenaarioiden tarkastelut ja niistä keskustelu auttavat pohtimaan tulevaisuutta myönteisessä valossa mutta samalla kuitenkin kriittisesti. 
Suomen ilmastopaneelin mukaan alakoulun ilmastokasvatuksessa on monia tavoitteita (Ratinen ym., 2019). Ensiksi opetuksessa tulee kiinnittää huomiota ilmastonmuutoksen ilmiöön, sen syihin ja seurauksiin (Shepardson ym., 2012). Lisäksi ratkaisukeskeisessä ilmastokasvatuksessa tulee oppilaille tarjota mahdollisuuksia tutustua ilmastonmuutoksen ratkaisukeinoihin. Toiseksi opetussisältöjen tulee olla sellaisia, että oppijan syy-seuraus-suhteiden ymmärtäminen paranee ja kriittisen ajattelun taidot kehittyvät monipuolisia tehtäviä ratkoessa (Lombardi, Sinatra \& Nussbaum, 2013). Kolmanneksi oppijan tulisi omaksua osana oppimista ilmastovastuullinen identiteetti (Tolppanen ym., 2017) sekä hänen asenteiden, arvomaailman ja maailmankuvan muodostumisen tukeminen tulisi olla keskeinen osa oppimisprosessia. Neljänneksi oppimisprosessin tulisi osallistaa ja motivoida oppijaa toimimaan kestävästi yhdessä yhteisen ympäristön hyväksi (Degerman, 2016). Viidenneksi oppilaiden tulisi pystyä alakoululaiselle tarkoituksenmukaisella tavalla yhteiskunnalliseen vaikuttamiseen ja toiminnan harjoittelemiseen, kuten oman lähiympäristön kestävän kehityksen mukaiseen suunnittelemiseen. Kuudenneksi ilmastokasvatuksessa on tärkeää korostaa ilmastonmuutokseen liittyvien tunnetaitojen kehittymisen tukemista ja harjoittelemista (Ojala, 2012b; Pihkala, 2019b). On tärkeää, ettei oppilas jää yksin ilmastonmuutokseen liittyvien tunnetilojen kanssa. Seitsemäntenä alakoulun ilmastokasvatuksen tavoitteena on erilaisten tulevaisuuskuvien tarkastelu (Hicks, 2014). Viimeinen, mutta todella tärkeä alakoulun ilmastokasvatuksen tavoite on realistisen toivon valaminen ja vaaliminen (Pihkala, 2017a), joka kumpuaa edellä kuvatun kaltaisesta opetuksesta ja kokoaa tavoitteet yhteen. Ilmastonmuutoksen hillitsemisen ja siihen sopeutumisen näkökulmasta meillä aikuisilla ei ole oikeutta olla saattamatta lapsia ilmastonmuutoksen tieteellisen tiedon lähteille. Toisaalta meidän tulee varmistaa se, että emme maalaa lasten maailmaa jo valmiiksi mustaksi. Meidän tulee aikuisina, kasvatustieteellisiin ja -psykologisiin tutkimuksiin (Ojala \& Bengtsson, 2019; Ratinen \& Uusiautti, 2020) perustuen luoda lapsille oppimisen kautta usko siihen, että he rakentavat tulevaisuutta.

\section{Tutkimuksen tarkoitus}

Huolimatta siitä, että ilmastonmuutokseen liittyvästä opetuksesta tiedetään varsin paljon, on edelleen epäselvää, millaisia ajatuksia alakoulun oppilailla on ratkaisukeskeisen ilmastokasvatuksen toteutuksesta ja siihen, miten kasvatus vaikuttaa tunteisiin. Tässä tutkimuksessa tuodaan esille lapsen kokemuksen ääni ilmastokasvatukseen osallistumisesta. Tämä oppilaiden vastausten sisällönanalyysiin ja fenomenografiseen teemoitteluun perustuva tutkimus on tehty osana Suomen ilmastopaneelin ilmastokasvatushanketta, joka toteutettiin vuosina 2017-2019 yhdessä luokanopettajaopiskelijoiden kanssa. Hankkeessa kehitettiin prosessimalli ratkaisukeskeiseen ilmastokasvatukseen. Ilmastokasvatuksen prosessimalliksi nimetty malli on luettavissa Ratisen ja kollegoiden (2019) raportista. Tämä tutkimus kuvaa oppilaiden ajatuksia prosessimalliin liittyvien ilmastokasvatusikkunoiden sisällöistä ja avaa oppilaiden näkemyksiä tutkivasta vuorovaikutteisesta ilmastokasvatuksesta. 
Tutkimuksessa haetaan vastausta seuraavaan tutkimuskysymykseen:

- Millaisia kokemuksia oppilailla on ratkaisukeskeisestä ilmastonmuutoksen opetuskokonaisuudesta ja sen vaikutuksesta heidän tunteisiinsa?

\section{Aineisto ja menetelmät}

Tutkimuksen aineisto hankittiin avoimella kyselylomakkeella kahdeksasta alakoulun luokasta ilmastonmuutosta käsittelevän viimeisen opetuskerran päätteeksi (Taulukko 1). Luokanopettajaopiskelijat ohjeistettiin vaiheistamaan opetus siten, että kaikissa luokissa käytiin ensimmäisellä opetuskerralla läpi ilmastonmuutos ilmiönä. Seuraavilla kerroilla oppilaat pohtivat ratkaisukeskeisesti, kuinka ilmastonmuutosta voidaan konkreettisesti hillitä tai kuinka siihen voidaan sopeutua. Ensimmäisellä opetuskerralla opetuskeskusteluiden avulla kartoitettuja oppilaiden ennakkokäsityksiä ja heidän ideoitaan opetettavista sisällöistä hyödynnettiin eri luokkien opetussisältöjen suunnittelussa. Oppilaspalautetta koskeva opetus oli luokanopettajaopiskelijoiden suunnittelemaa, mutta he hyödynsivät suunnittelussa oppilaiden ajatuksia ja näkökulmia. Uitto, Boeve-de Pauw ja Saloranta (2015) ja Saloranta (2017) ovat tutkimuksissaan esittäneet, että oppijoiden toimijuus (in-school agency) vaikuttaa positiivisesti muun muassa oppilaiden omiin kykyihin ja ympäristömyönteiseen käyttäytymiseen.

Tässä ratkaisukeskeisessä ilmastokasvatuskokonaisuudessa oppilaiden toimijuutta edistettiin erityisesti siten, että he saivat miettiä ratkaisuja ilmastonmuutokseen omassa arjessaan esiintyvien asioiden kautta. Lapset pohtivat esimerkiksi öljyn merkitystä omassa arjessa ja sen jälkeen luokanopettajaopiskelijat suunnittelivat, kuinka oppilaiden ajatukset voidaan kytkeä arktiseen öljyntuotantoon ja siihen liittyviin ympäristöongelmien ratkaisuun. Ratkaisukeskeisyys ja oppilaslähtöisyys toteutuivat esimerkiksi siten, että oppilaat tutkivat öljyntorjunnan perusteita ja öljyn kuluttamisen vähentämisen vaikutusta ilmastonmuutokseen. Opetuksen suunnittelu liittyi opiskelijoiden kuuden opintopisteen projektikurssiin, jossa tehtiin yhteistyötä Suomen ilmastopaneelin kanssa. Ilmastonmuutosta koskevan opetuskokonaisuuden opetusmenetelmät suunniteltiin tutkivan ja vuorovaikutteisen tutkivan oppimisen mukaisesti (Ratinen, 2016). Opetuksen suunnittelussa ja sisältöjen valinnassa hyödynnettiin Andersonin (2012) korostamia näkökulmia:

- Sovellettiin jatkuvan ja aktiivisen projektioppimisen periaatteita hyödyntämällä integroituja, monialaisia opetussuunnitelmia

- Kytkettiin oppiminen paikalliseen ongelmanratkaisuun

- Korostettiin toivon näkökulmaa ja kriittisen ajattelun taitoja

- Etsittiin ratkaisuja ilmastotiedon hyödyntämiseen hiilijalanjäljen vähentämiseksi

- Hyödynnettiin hiilijalanjälkilaskureita ilmastonmuutoksen hillitsemisen vaikutuksen arvioimiseksi 
- Opetuksessa käytettiin apuna kertomuksia, oppilaiden visualisoimia kuvia, vakuuttavia tekstejä sekä asiantuntijoiden tietoa

Taulukko 1. Opetuksen sisällöt luokka-asteittain ja luokkien oppilasmäärät. Kaikissa luokissa opetus aloitettiin ilmastonmuutoksen syiden ja seurausten läpikäynnillä.

\begin{tabular}{|c|c|c|}
\hline Luokka-aste & Opetuksen aihe & Oppilasmäärä \\
\hline 5. luokka & $\begin{array}{l}\text { - Uusiutuvat ja uusiutumattomat luonnonvarat } \\
\text { (luokittelutehtävä ja pohdintaa kytköksistä } \\
\text { ilmastonmuutokseen } \\
\text { - Climate hero -peli } \\
\text { - Ruokareseptit ja } \mathrm{CO}_{2} \text {-laskurilla lasketut } \\
\text { ruuan hiilijalanjäljet } \\
\text { - } \mathrm{CO}_{2} \text {-hippa ulkona }\end{array}$ & 15 \\
\hline 6. luokka & $\begin{array}{l}\text { - Erilaisten ruokien hiilijalanjäljet ja ilmasto- } \\
\text { ystävällisen dieetin suunnittelu ja laskenta } \\
\text { - Uusien ilmastoystävällisten ruokien maiste- } \\
\text { leminen (mm. satokausivihannekset, kaura- } \\
\text { valmisteet, sirkkapatukat jne.) }\end{array}$ & 20 \\
\hline 6. luokka & $\begin{array}{l}\text { - } \mathrm{CO}_{2} \text { valmistus ja koe hiilidioksidin vaikutuk- } \\
\text { sesta lämpötilaan } \\
\text { - Lautapeli hiilen kiertokulusta } \\
\text { - Operaatio Tuvalu } \\
\text { - Ajatuksia kokoava piirros tai kirjoitelma } \\
\text { ilmastonmuutoksesta }\end{array}$ & 25 \\
\hline 6. luokka & $\begin{array}{ll}\text { - } & \mathrm{CO}_{2} \text {-koe } \\
\text { - } & \text { Öljyntorjuntademonstraatio } \\
\text { - } & \text { Piirrostehtävä ilmastonmuutokseen liittyvistä } \\
& \text { tekijöistä } \\
\end{array}$ & 16 \\
\hline 6. luokka & $\begin{array}{l}\text { - Ilmastonmuutoksen vaikutus eläimiin } \\
\text { - Ilmastonmuutokseen vaikuttaminen } \\
\end{array}$ & 20 \\
\hline 5. luokka & $\begin{array}{l}\text { - Öljyntuotanto arktisella alueella ja sen yhtey- } \\
\text { det ilmastonmuutokseen }\end{array}$ & 22 \\
\hline 6. luokka & $\begin{array}{l}\text { - } \text { Climate hero -peli ja hiilijalanjälki } \\
\text { - Kuluttamisen vaikutus ilmastonmuutokseen } \\
\text { - Ruuan ilmastovaikutukset } \\
\text { - } \quad \text { Ympäristöystävällinen kulkuneuvo } \\
\end{array}$ & 17 \\
\hline 6. luokka & $\begin{array}{ll}\text { - } & \text { Ruokavalion vaikutus ilmastonmuutokseen } \\
\text { - } & \mathrm{CO}_{2} \text {-laskurilla lasketut ruuan hiilijalanjäljet }\end{array}$ & 17 \\
\hline
\end{tabular}

Tutkimusaineisto koostui 152 oppilaan vastauksista. Oppilaat olivat niiltä luokilta, joiden opettajat ilmaisivat halukkuutensa osallistua ilmastopaneelin ilmastokasvatusprojektiin. Opettajien halukkuutta osallistua kartoitettiin sähköpostitse Rovaniemen alakouluista. Mukaan lähteneiden luokkien kaikilla tutkimukseen osallistuvilla oppilailla oli kirjallinen huoltajan suostumus tutkimukseen osallistumisesta. Tutkimuslomakkeessa oppilaita pyydettiin vapaamuotoisesti kirjoittamaan vastaukset seuraaviin kysymyksiin: Mitä uusia asioita opit tänään? Lisäsikö jokin toivoasi ilmastonmuutosta kohtaan, jos, niin mikä? Mikä työpajassa sai sinut kiinnostumaan enemmän ilmastonmuutoksesta, sen hillitsemisestä ja siihen sopeutumisesta? Tekikö jokin työpajassa esille tullut asia sinut surulliseksi ja jos, niin miksi? Aineistonkeruun aikana oppilaille annettiin 
mahdollisuus kysyä tarkemmin, mitä eri kysymyksillä tarkoitettiin. Aineistonkeruuseen meni aikaa 20-30 minuuttia.

Sisällönanalyysiin ja fenomenografiaan perustuva aineistonanalyysi tehtiin molempien tutkijoiden yhteistyönä ja siinä hyödynnettiin tutkijatriangulaatiota (Denzin, 2017). Oppilaille esitetyt kysymykset ohjasivat oppilaiden vastauksia ja vaikuttivat muodostuneisiin teemoihin, jonka vuoksi ei voida puhua puhtaasta aineistolähtöisestä induktiivisesta analyysistä (Sarajärvi \& Tuomi, 2017). Näin käy usein lasten vastauksia tutkittaessa. Tutkimuksessa aineiston raaka-analyysi tehtiin sisällönanalyysin avulla, jonka jälkeen kyettiin teoriasidonnaisesti muodostamaan käsitekategoriat. Analyysi aloitettiin lukemalla kaikki vastaukset läpi ja teemoittamalla ne kysymyksittäin teemoihin, kuten oppimiseen. Seuraavassa vaiheessa tarkasteltiin sitä, kuinka erilaiset teemat muodostivat kategorioita. Esimerkiksi oppimisteemassa oppilaat kirjoittivat oppineensa kasvihuoneilmiöstä ja öljyntorjunnasta. Kolmannessa vaiheessa oppilaiden vastauksissa muodostuneita teemoja tarkasteltiin oppituntien yhteydessä. Muodostetuista kategorioista ei laskettu tutkijoiden luokittelun eroa kuvaavaa Cohenin kappaa, sillä oppilaiden vastaukset olivat lyhyitä ja yksiselitteisiä, joten niissä ei ollut tulkinnanvaraa. Sen sijaan tutkijat pohtivat yhdessä, mitkä oppilaiden vastauksista liittyivät tiettyyn kategoriaan. Tässä laadullisessa tutkimuksessa ei tarkastella kategorioiden pohjalla olevia käsitteitä määrällisesti. Tutkimuksessa ei myöskään selitetä ja etsitä eroja taustamuuttujien, kuten sukupuolen ja luokka-asteen välille. Tutkimuksessa tarkastellaan teoriasidonnaisesti ainoastaan sitä, kuinka oppituntien aiheet näkyivät oppilaiden kirjoittamissa kokemuksissa. Tuloksien yhtymäkohtia teoriaan tarkastellaan teoriasidonnaisten löydösten yhteydessä. Tulosten pohdinnassa peilataan tuloksia ratkaisukeskeisen ilmastokasvatuksen toteutuksen näkökulmasta.

\section{Tulokset}

Analysoitaessa tuloksia ratkaisukeskeisen ilmastokasvatuksen toteutumisesta alakoulun oppilaiden näkökulmasta teemoitettiin 152 oppilaan vastaukset seuraavien käsitekategorioiden alle: 1) uuden oppiminen, 2) kiinnostuksen lisääntyminen, 3) ilmastonmuutokseen liittyvä toivo ja 4) ilmastonmuutokseen liittyvä suru.

\section{Uuden oppiminen}

Ilmastonmuutoskokonaisuudet suunniteltiin ilmastonmuutoksen ilmiön ymmärtämisen osalta ratkaisukeskeisiksi, joten on luontevaa tarkastella, kuinka opettavaiseksi oppilaat ne kokivat. Tässä artikkelissa ei tarkastella sitä, mitä oppilaat oppivat. Opetuksen taso pidettiin alakoululaisille sopivana, joten esimerkiksi kasvihuonekaasujen vuorovaikutusta lämpösäteilyn kanssa ei käsitelty. Opetuksessa tavoitteena oli, että alakoululaiset ymmärtävät kasvihuonekaasujen ilmastoa lämmittävän vaikutuksen, kasvihuonekaasujen alkuperän ja ihmisten mahdollisuudet hillitä ilmastonmuutosta. Opetuksen suunnittelu perustui ilmastonmuutoksen virhekäsitysten vähentämiseen (Ratinen \& Vettenranta, 2018). Kun oppilailta kysyttiin, mitä uusia asioita he kokivat oppineensa, nousi oppilaiden vastauksista esille kolme pääteemaa (Kuvio 1). Oppilaat kirjoittivat oppineensa: 1) uusia asioita kasvihuonekaasuista ja kasvihuoneilmiöstä, 2) sen, 
kuinka hiilidioksidia pystyy itse valmistamaan sekä 3) sen, kuinka haastavaa veden puhdistaminen öljyvuotojen jälkeen on.

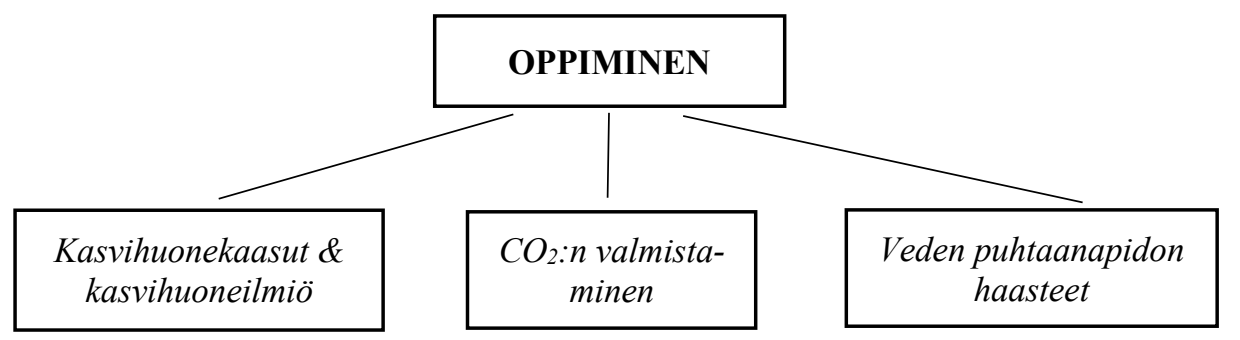

Kuvio 1. Oppilaiden vastauksista muodostuneet kategoriat uuden oppimisen kokemuksen sisällöistä.

Oppilaiden kokemus oppimisesta oli selkeässä yhteydessä etenkin siihen oppituntiin, jonka aikana kysely tehtiin. Oppilaiden ilmastonmuutokseen liittyvä oppimiskokemus antaa viitteitä siitä, että heidän on vaikea yhdistää ilmastonmuutokseen vaikuttavia tekijöitä ja näin hahmottaa ilmastonmuutoksen oppimista kokonaisuutena. Tulosta voi verrata aikaisempien tutkimusten johtopäätöksiin, jotka paljastavat, että niin lapsien kuin aikuisten on vaikea oppia ilmastonmuutos luonnontieteellisesti oikein (Lambert, Lindgren, \& Bleicher, 2012; Ratinen, 2016). Tämän tutkimuksen aineiston perusteella ei kuitenkaan pysty selvittämään, millä tasolla oppilaat olivat ilmastonmuutoksen oppineet. Sen sijaan aineisto kertoo, että oppilaiden oppimiskokemukseen vaikutti oppitunnin sisältö, erityisesti kokeellisuus. Kokeellisen työskentelyn aikana selvästi näkynyt oppilaiden ilo ja innostus ovat todennäköisesti lisänneet heidän opiskelumotivaatiotaan.

Tunteiden vaikutukset eivät kuitenkaan aina ole yksiselitteisiä, sillä pelko tai suru voivat heikentää motivaatiota, mutta esimerkiksi viha voi joissain tilanteissa myös lisätä motivaatiota (Pekrun, 2016, s. 130). Esimerkiksi kuudennella luokalla toteutettu koe hiilidioksidin vaikutuksesta lämpötilaan oli oppilaiden mielestä selvä oppimisen kokemus. Myös muu konkreettinen tekeminen, kuten öljyntorjuntademonstraatio koettiin opettavaiseksi. Oppilaat kokivat oppineessa ilmastonmuutoksen hillinnästä, mutta vastaukset eivät kuitenkaan muodostaneet selkeää yhteyttä oppituntien tavoitteisiin. Tulos antaa viitteitä siitä, että ratkaisukeskeisen ilmastokasvatuksen todentuminen on alakoulussa vaikeaa, mihin saattaa vaikuttaa esimerkiksi se, että tutkittavat asiat jäävät oppilaille liian etäisiksi. Tämä näkyy erityisesti ruoan ilmastovaikutusten tarkastelussa. Vain harva oppilas oli kokenut oppineensa ruuan ilmastovaikutuksista ja jokaisen mahdollisuudesta pienentää hiilijalanjälkeään ruokavalion avulla, vaikka se oli opetuksen tavoite. Yllättäen myöskään Climate hero -peli, jossa pohdittiin liikkumisen ilmastovaikutuksia ja niiden ratkaisuja ilmastonmuutoksen vastaisessa työssä ei näkynyt juurikaan oppilaiden vastauksissa. Erityisen kiinnostavaa on, että aineiston perusteella osa oppilasta arveli ilmastonmuutoksen hillitsemisen mahdolliseksi, mutta ilmastonmuutoksen lopettamisen mahdottomaksi. 


\section{Kiinnostuksen lisääminen}

Salmela-Aron (2018) mukaan oppimismotivaatioon vaikuttaa moni tekijä, kuten oppilaan kiinnostus opetettavaa aihetta kohtaan. Pekrun (2016) korostaa tunteiden merkitystä oppimiseen niiden oppimismotivaatioon vaikuttavan yhteyden kautta. Tässä tutkimuksessa oppilaille esitetty kysymys siitä, mikä työpajassa sai heidät enemmän kiinnostumaan ilmastonmuutoksesta, sen hillitsemisestä ja siihen sopeutumisesta oli oppilaille vaikea. Suurin osa oppilaista vastasi: "ei mikään". Kuitenkin vastauksista nousi esiin kaksi selkeää teemaa, joihin myös tunteiden ja tehtävien ratkaisukeskeisyyden voidaan katsoa olevan kytköksissä (Kuvio 2). Kiinnostusta ilmastonmuutoksen hillintään ja sopeutumista kohtaan lisäsivät: 1) tieto jäätiköiden sulamisen vaikutuksista jääkarhujen ja muiden jäätikköalueella elävien eläinten elinolojen heikkenemisestä ja sukupuuttoon kuolemisesta sekä 2) tieto öljyn puhdistamisen ja sen kuljettamisen haasteista ja ongelmista.

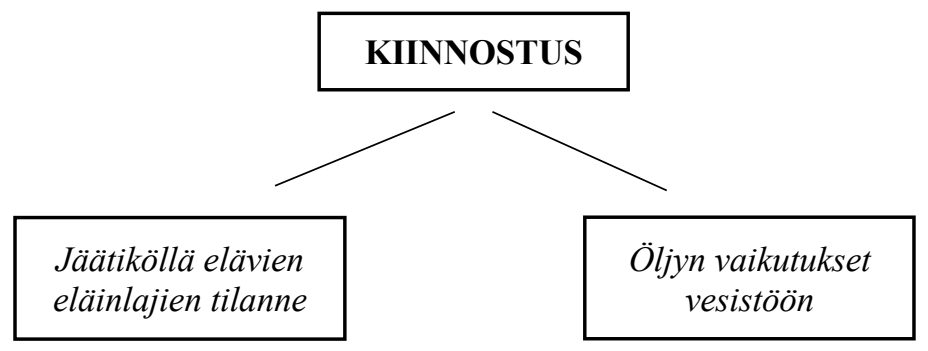

Kuvio 2. Oppilaiden vastauksista muodostuneet kategoriat uuden oppimisen vaikutuksesta kiinnostukseen.

Tulosten perusteella näyttäisi siltä, että oppilaat kiinnostuivat ilmastonmuutoksesta ja siihen vaikuttamisesta silloin, kun sen seurauksia pohdittiin muiden lajien näkökulmasta. Toisaalta yhdessä luokassa tutustuttiin Operaatio Tuvalu -tehtävän avulla ilmastonmuutoksen aiheuttavan merenpinnan nousun vaikutukseen Tyynellämerellä olevan saaren olemassaoloon. Tehtävässä oppilaat pääsivät pohtimaan ilmastonmuutoksen vaikutuksia toiseuden näkökulmasta. Ilmastonmuutos on niin ajallisesta kuin paikallisesta näkökulmasta vaikea ilmiö hahmottaa (van der Linden, Maibach \& Leiserowitz, 2015). Ilmastonmuutos on hidasta ja se tapahtuu suomalaista yhteiskunnasta tarkasteluna kaukana. On mahdollista, että kun oppilaat asettuivat kuvitteellisesti sellaisen ihmisen asemaan, jonka elämään ilmastonmuutos vaikuttaa konkreettisesti, tämä lisäsi kiinnostusta myös ilmastonmuutoksen hillitsemistä kohtaan. Oppilaat myös kaipaavat konkreettisia esimerkkejä ilmastonmuutoksesta, sillä kuvat jäätiköiden vetäytymisestä, esimerkit luonnonvarojen hyödyntämisistä ja vaikutuksista alkuperäiskansoihin lisäsivät heidän kiinnostustaan. Öljyntorjuntademonstraatio oli selkeä ratkaisukeskeinen oppilaslähtöinen ongelmaratkaisutehtävä ja se lisäsikin oppilaiden kiinnostusta. Ilmastonmuutoksen hillintä nähtiin myös positiivisessa mielessä, sillä osa oppilaista koki, että ilmastonmuutoksen hillintä voi tuoda omaan arkeen myös myönteisiä asioita, kuten uusia ruokalajeja. On huomionarvoista, että jokaisessa luokassa oli myös oppilaita, jotka kertoivat opetuksen ja sen sisältöjen lisänneet heidän kiinnostustaan ilmastonmuutosta kohtaan. Ainostaan yksi 
oppilas vastasi, että tulevaisuudessa lämpötilan nousu lisäsi hänen kiinnostustaan ilmastonmuutoksesta.

\section{Ilmastonmuutokseen liittyvä toivo}

Viime aikoina on kiinnitetty erityistä huomiota ilmastonmuutokseen liittyvään toivoon (Ojala, 2012a; Pihkala, 2017b, Ratinen ym., 2019). Tässä tutkimuksessa toteutetut opintokokonaisuudet suunniteltiin merkityksellisiksi ja ratkaisukeskeiseksi. Näistä näkökulmista on myös positiivista tutkimusnäyttöä (Ojala \& Bengtsson, 2019). On kuitenkin otettava huomioon, että myös merkityskeskeinen opetus vaikuttaa oppijoiden tunteisiin. Opettajan tulee olla tietoinen, että jotkut oppilaat voivat kokea positiiviset ratkaisukeskeiset viestit (ilmastonmuutosta voidaan hillitä) heidän tunteidensa vähättelynä. Pihkala (2019a) painottaa, että tarvitaan tunteiden kohtaamista, ongelmaratkaisukykyä ja omien vaikutusmahdollisuuksien kokemisen tarvetta. Kahdeksan oppitunnin jälkeen oppilailta kysyttiin, lisäsikö jokin toiveikkuuttasi ilmastonmuutosta kohtaan. Oppilaiden vastauksista nousi esiin kaksi teemaa (Kuvio 3). Oppilaiden keskuudessa ilmastonmuutosta koskevaa toiveikkuutta lisäsi: 1) tieto siitä, että pystymme omalla toiminnallamme hidastamaan ilmastonmuutoksen etenemistä sekä 2) se, että biopolttoaineiden ja uusien liikkumismuotojen hyödyntäminen tulevaisuudessa kannattaa. Molemmat teemat liittyvät ilmastokasvatuksen ratkaisukeskeisyyteen ja toivon kokemisen väliseen yhteyteen. Kun oppilaat kokivat, että he voivat toimillaan vaikuttaa ilmastonmuutokseen, samalla lisääntyi heidän toivonsa ilmastonmuutosta kohtaan.

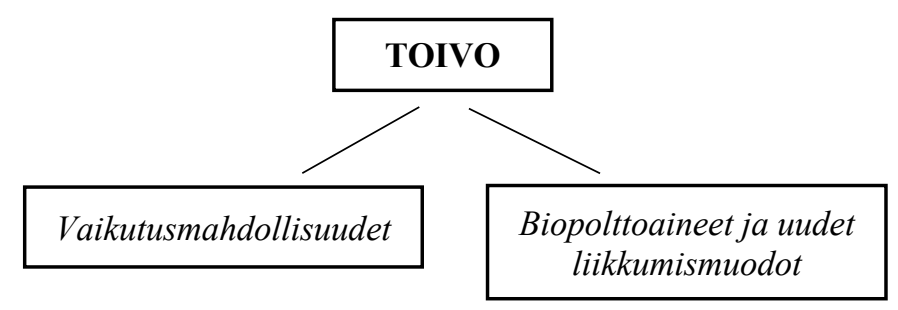

Kuvio 3. Oppilaiden vastauksista muodostuneet kategoriat ilmastonmuиtokseen liittyvästä toivosta.

Olisi ollut toivottavaa, että oppilaat olisivat ilmaisseet toivoon liittyvää kysymystä monisanaisemmin kuin usein vastaamalla, että "ei mikään". Tarkastellessa oppilaiden vastauksia yksityiskohtaisemmin vastauksista löytyy selviä yhtymäkohtia oppituntien sisältöihin ja ilmastokasvatuksen ratkaisukeskeisyyteen. Esimerkiksi silloin kun oppitunneilla on käsitelty ruoan ilmastovaikutuksia, on ilmastoystävällisten dieettien suunnittelu lisännyt oppilaiden toivoa. Samalla tavalla oppilaat kokevat, että liikkumismuotoja kehittämällä lisätään samalla toivoa, sillä nämä liikkumismuodot vähentävät ilmastopäästöjä. Liikkumisen ja biopolttoaineiden liittyminen toisiinsa rinnastui selvästi sellaisiin oppitunteihin, jossa aihetta käsiteltiin enemmän esimerkiksi ympäristöystävällisen kulkuneuvon suunnittelutehtävän avulla. Koska oppitunneilla ei teemallisesti käsitelty kuin yhdessä luokassa WWF:n ilmastokorttien avulla asumisen vaikutuksia ilmastonmuutokseen, ei tämä teema myöskään näkynyt oppilaiden vastauksissa. Varsin monet kokivat, että lisääntynyt tietous ilmaston- 
muutoksesta ja motivoiva aihe, kuten kuluttaminen, olivat lisänneet heidän toivoaan. Erityisen positiivista oli, että useissa luokissa oli oppilaita, joka kokivat omien vaikutusmahdollisuuksien lisäävän heidän toivoaan ilmastonmuutosta kohtaan.

\section{Ilmastonmuutokseen liittyvä suru}

Pihkala (2017a, 2019b) on käsitellyt ilmastonmuutokseen liittyvää surua. Lapsen surussa on tärkeä myötäelää ja ymmärtää, että lapsi voi kokea ilmastonmuutoksen dramaattisemmin kuin aikuinen. Ojalan (2012b) mukaan lapset hallitsevat aikuisia vähemmän omaa ilmastonmuutokseen liittyvää käytöstä. Tästä syystä ongelmakeskeiset ilmastonmuutoksen selviytymisstrategiat saavat heidät huolestuneemmiksi sen sijaan, että ne auttaisivat heitä paremmin hallitsemaan tilannetta. Tämän vuoksi tähän tutkimukseen liittyvässä opetuksessa luotiin oppilaille merkityksellisiä ja ratkaisukeskeisiä heidän omaan arkeensa liittyviä oppimiskokonaisuuksia. Koska oppilailla on vähän mahdollisuutta vaikuttaa ratkaisukeskeisiin asumisesta johtuviin ilmastotoimiin kuten kodin lämmitysjärjestelmän muuttamiseen, jätettiin teema pois opetuksesta. Kun oppilailta kysyttiin opetuksen jälkeen, tekikö jokin työpajassa esille nousseista asioista sinut surulliseksi, iso osa oppilaista vastasi: "ei tehnyt". Tämän lisäksi vastauksista nousi esille kaksi teemaa (Kuvio 4). Oppilaiden vastauksissa surua aiheuttivat: 1) Lintujen kuolema ja kärsiminen vesistöön joutuneen öljyn vuoksi sekä 2) jäätiköiden sulamisen seurauksena eläinten, etenkin jääkarhujen, kärsiminen ja jopa mahdollinen sukupuuttoon kuoleminen.

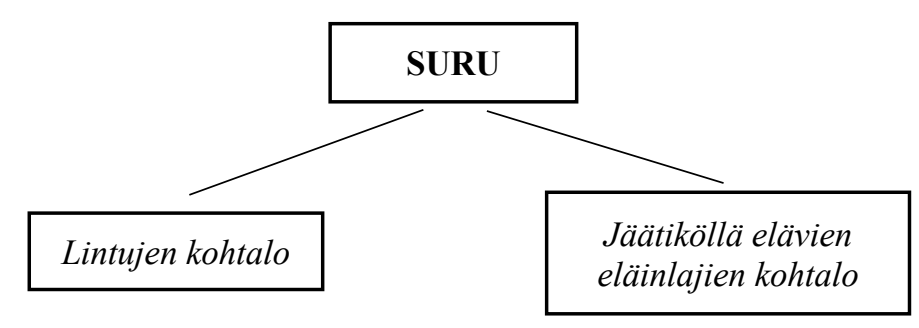

Kuvio 4. Oppilaiden vastauksista muodostuneet kategoriat ilmastonmuutokseen liittyvästä surusta.

Oppituntien sisällöillä oli myös suruun liittyvässä kysymyksessä suuri merkitys oppilaiden vastauksiin. Lintujen kärsiminen liittyi erityisesti niihin oppitunteihin, joissa käsiteltiin öljyonnettomuuden vaikutusta ympäristöön. Myös jäätiköillä elävien eliöiden elinympäristöjen kutistuminen oli oppilaiden mielestä surullista. Etenkin jääkarhu on ilmastonmuutoksen symbolieläin ja siitä kerrottiin jossakin määrin kaikilla eri luokilla. Lohdullista on, että suurin osa oppilaista ei kokenut omien sanojensa mukaan surua opetuksen jälkeen. Toisaalta aineistossa oli myös yksittäisiä oppilaita, jotka kokivat ihmisen toiminnan ja ilmastonmuutoksen vakavuuden sekä sen hillitsemisen vaikeuden lisäävän surua. Tässä mielessä ratkaisukeskeisellä ilmastokasvatuksella on iso haaste saada luotua toivoa ilmastonmuutoksen hillitsemiseen. 


\section{Tulosten pohdinta}

Kaikissa kahdeksan tunnin oppituntikokonaisuuksissa tavoitteena oli ilmastonmuutoksen syiden, seurausten ja hillinnän oppiminen erilaisten ratkaisukeskeisten esimerkkien avulla. Oppilaat kuvasivat oppineensa yksittäisiä ilmastonmuutokseen liittyviä seikkoja, mutta ei niinkään ilmastonmuutosta kokonaisuutena. Tulos ei ole yllätys, sillä myös aikuisilla, kuten luokanopettajaopiskelijoilla, on vaikeuksia ymmärtää ilmastonmuutokseen liittyvää opetusta (Ratinen, 2016). Toisaalta on tullut esille, että oppilaiden on varsin vaikea kuvata oppimistaan ja sen yhteyttä ilmastonmuutokseen. Esimerkiksi PISA-tutkimuksessa (Ratinen \& Vettenranta, 2018) oppilaiden itsearvioidulla ympäristötietoisuudella oli positiivinen yhteys heidän ilmastonmuutostietouteen, mutta korrelaatiot jäivät varsin pieneksi $(<0,3)$. Oppilaiden vastauksista paljastui kuitenkin luonnontieteellisen konkreettisen tekemisen, kuten hiilidioksidin vaikutuksen tutkimisen ja öljyn puhdistamisen, näkyminen heidän oppimiskokemuksissaan.

Abrahams ja Millar (2009) ovat osoittaneet, että kokeelliset työt ovat silloin tehokkaita, kun oppijat tietävät, mitä heidän tulee tehdä kokeessa. Tähän tutkimukseen liittyvissä kokeellisissa töissä ratkottiin ilmastonmuutokseen liittyviä ongelmia konkreettisen tekemisen avulla. Oppilaat eivät kuitenkaan kokeneet pelillisiä ratkaisuja opettavaisina ainakaan siinä mielessä, että he olisivat nostaneet peleissä esitettyjä asioita selkeästi esille. Tulos on kiinnostava siitä näkökulmasta, että oppilaat saivat osallistua pelien sisällön kehittämiseen ja niissä tarjottiin ratkaisuja ilmastonmuutoksen hillintään, kuten siihen, kuinka liikennevälineiden vaihtamisella voidaan konkreettisesti pienentää omaa hiilijalanjälkeä. Opetuksen seuranta kuitenkin paljasti, että oppilaiden osaaminen ja osallistuminen on hyvin myönteistä ja iloista niin hiilidioksidihipassa, hiilikiertopelissä kuin ilmastosankaripelissä. Tunteiden vaikutusta oppimismotivaatioon tulisi kuitenkin tutkia lisää (Pekrun, 2016) myös ilmastokasvatuksen yhteydessä. Oppilaat olivat jatkaneet pelien kehittämistä ja yksi viidennen luokan opettaja kertoi myöhemmin, että oppilaat olivat tehneet hiilidioksidihipasta nuorimmille koululaisille oman välituntileikkiversion.

Monroe, Plate, Oxarart, Bowers ja Chaves (2019) löysivät metatutkimuksessaan neljä teemaa, joiden avulla voidaan lisätä oppijoiden kiinnostusta ja motivaatiota ilmastonmuutoksen opetusta kohtaan. Näitä teemoja olivat (1) keskusteleminen ilmastonmuutoksen aihealueista, (2) vuorovaikutus tutkijoiden kanssa, (3) väärinkäsitysten käsitteleminen ja (4) koulu- tai yhteisöhankkeiden toteuttaminen. Nämä aihealueet olivat keskeisesti mielessä, kun opiskelijat suunnittelivat Andersonin (2012) ajatuksia mukailevia oppitunteja. Tämän tutkimuksen mukaan opiskelijoiden laatimat tehtävät ja ratkaisukeskeiset harjoitukset eivät olleet niin kiinnostavia oppilaiden mielestä kuin me aikuiset kuvittelimme niiden olevan. Tulos on sikäli merkittävä, että oppilaat saivat itse myös osallistua oppitunneilla esitettyjen sisältöjen valintaan. Se on kuitenkin selvää, että alakoululaiset arvostavat konkreettista tekemistä.

Ratisen ja Uusiautin (2020) laajan oppilasaineiston mukaan rakentavan toivon ja ilmastonmuutoksen hillitsemisen tietoudessa on selkeä yhteys. Tämä laadullinen tutkimus tukee osittain tätä näkemystä, sillä 
oppilaiden kokemukset vaikuttamisen mahdollisuuksista kasvattivat heidän toivoaan ilmastonmuutosta kohtaan. Ratinen ja Uusiautti (2020) nostavat esille neljä oppilastyyppiä, joiden hahmottaminen voisi hyödyntää ilmastonmuutoksen pedagogiikan suunnittelua. Ensiksi on oppilaita, joilla on syvä tietämys ja rakentava toivo. Tämä asema viittaa oppilaisiin, jotka ovat tietoisia ilmastonmuutoksen merkityksestä ja sen hillintätoimista. He ovat tietoisia oman käyttäytymisensä vaikutuksista ja tietävät kykynsä ja mahdollisuutensa toimia ympäristöystävällisesti. Tämän vuoksi heillä on toivoa tulevaisuuteen. Tällaisten oppilaiden ratkaisukeskeisessä ilmastokasvatuksessa kannattaisi antaa oppilaille avoimeen tutkivaan oppimiseen perustuvia tehtäviä (Banchi \& Bell, 2008), kuten tässä tutkimuksessa tehtiin. Koska tämä tutkimus kosketti alakoulun oppilaita, tutkivan oppimisen avoimuus rajautui opettajan viimeistelemään tutkimusasetelmaan esimerkiksi hiilidioksidikokeessa. Oppilaiden kysymykset kuitenkin ohjasivat sosiokulttuurista oppimista.

Toiseksi on oppilaita, joilla on syvä tietous, mutta he ovat menettämässä toivon. Heidän asenteensa ja kykynsä vaikuttaa muiden toimintaan on melko pessimististä. He pelkäävät ilmastonmuutoksen kehitystä tavalla, joka voi aiheuttaa heille ahdistusta, jopa masennusta. Jotta tämän kaltaiset oppilaat eivät menettäisi toivoa, tulisi heille kertoa onnistuneista ympäristötoimenpiteistä. Ojalan (2012a, 2012b, 2019) tutkimukset osoittavat, että toivonsa menettäville oppilaille kannattaa antaa tehtäviä, jotka luovat merkityksiä ja mahdollistavat, että oppilaat voivat kohdata omat tunteensa tehtävän aikana.

Kolmanneksi on oppilaita, joiden ilmastonmuutostietous on pintapuolista, mutta heillä on silti rakentavaa toivoa. He ovat oppineet ilmastonmuutoksesta esimerkiksi koulussa, mutta he eivät pidä ilmastonmuutosta asiana, joka vaikuttaa heidän arkeensa paljon. Oppilaat osoittavat edelleen suurta optimismia tulevaisuutta kohtaan. He saattavat uskoa, että aktivistit ja poliitikot auttavat maita etsimään oikeita ratkaisuja ilmastonmuutoksen torjumiseksi. Tässä mielessä heidän toiveensa on rakentava, mutta heillä ei ole henkilökohtaista yhteyttä ilmastomuutokseen ja sen hillitsemiseen. Koska ilmastonmuutos vaikuttaa pitkällä aikavälillä kaikkien ihmisen elämään, olisi omat vaikutusmahdollisuudet vähäiseksi kokevat oppijat hyvä saada näkemään ilmastonmuutos kokonaisuutena esimerkiksi Tolppasen ja muiden (2017) kokonaisvaltaisen ilmastonmuutoskasvatuksen avulla.

Neljänneksi on oppilaita, joilla on pinnallinen ilmastonmuutostietous ja samalla kieltävä toivo. Heiltä puuttuvat oikeat tiedot ja he voivat perustaa mielipiteensä ilmastonmuutoksesta ennakkoluuloihin ja mielipiteisiin, joista on opittu esimerkiksi kotona. Varsinkin tässä ryhmässä vanhempien vaikutuksella voi olla negatiivisessa mielessä suuri rooli. Pihkala (2019b) avaa kiinnostavalla tavalla sukupolvien välistä eroa psykososiaalisella dynamiikalla eli sillä, että lapset ja vanhemmat ajautuvat muutenkin ristiriitoihin. Oppilaat, jotka ovat saaneet ilmastonmuutoksen kyseenalaistavan kotikasvatuksen, saattavat ajatella, että ilmastonmuutos ei ole todellinen tai että se on luonnollinen ilmiö, jonka hillitsemistä ei edes tarvita. Tämän tutkimuksen empiirisessä aineistossa tällaista kieltämistä ei tullut esille, mutta opetustilanteissa jotkut oppilaat toivat ilmi, ettei ilmastonmuutokseen kiinnitetä kotona mitään huomiota. Tähän 
luokkaan kuuluvien oppilaiden opetuksen suunnittelu ja toteuttaminen on iso haaste. Opetuksessa tulisi lähteä liikkeelle ilmastonmuutoksen perusasioista ja luoda opetuksesta merkityksellistä. Ilmastokasvattajan tulisi olla tietoinen, mihin luokkaan hänen oppijansa kuuluu ja antaa oppilaille tehtäviä sen perusteella. Tehtävien tulisi olla ratkaisukeskeisiä ja perustua realistiseen, rakentavaan toivoon.

Ilmastokasvatuksessa ei voi välttyä kaikilta osin siltä, että oppilaat kokevat opetuksessa alakuloa ja surua. Tämän tutkimuksen oppilasaineiston perusteella muiden lajien kärsimykset ilmastonmuutoksen vuoksi aiheuttavat surua. On selvää, että oppilaiden suru tulee ottaa huomioon ilmastokasvatuksessa. Tällöin oppilaita ei pidä jättää surun kanssa yksin. Toisaalta heille tulisi tarjota keinoja, kuinka itse voi vaikuttaa ilmastonmuutokseen hillitsevästi. Lasten oma-aloitteista ilmastotoimijuutta ja muita tapoja kanavoida ilmastonmuutosta kohtaan kokemiaan tunteita tulee tukea. O'Brien, Selboe ja Hayward (2018) jaottelevat tällaiset toimintamuodot kolmeen kategoriaan: maltillinen, radikaalimpi ja vastakulttuurillinen. Maltillisessa toiminnassa vaikutetaan perinteisin keinoin, kuten nuorisoaloitteiden avulla. Radikaalimpi toiminta tarkoittaa väkivallatonta kansalaistottelemattomuutta. Vastakulttuurillisessa toiminnassa erottaudutaan muusta yhteiskunnasta. Tavoitteellisessa ilmastokasvatuksessa suhtaudutaan varovaisesti radikaaleihin ja vastakulttuurillisiin toimenpiteisiin, sillä monilla lapsilla voi olla erilaisia taustoja ja jotkut voivat mennä herkästi tunnelukkoon.

O'Brien ja muut (2018) toteavat, että nuoret tarvitsevat mahdollisuuksia vaikuttaa esimerkiksi mielenosoituksien avulla. Tunteiden näkökulmasta mielenosoituksiin osallistumisen tulee olla vapaaehdoista, sillä kuten Ojala ja Bengtsson (2019) toteavat, vanhempien rooli vaikuttaa lasten ympäristötieteisuuteen. Pahimmillaan lapsi voi kokea olevansa kodin arvomaailman ja koulun opetusohjelman välisessä ristiaallokossa. Ratkaisukeskeisessä ilmastokasvatuksessa lääkkeeksi tähän ongelmaan tarjotaan tutkittua tietoa ilmastonmuutoksesta ja ilmastokasvatuksen ulottamista koko yhteiskuntaan (Ratinen ym., 2019). Kuten Chapman, Lickel ja Markowitz (2017) kirjoittavat, tunteet yhtenä olennaisena osana kognitiivista palautejärjestelmää ohjaavat päätöksenteko-ongelmien ratkaisussa. Tässä tutkimuksessa tarkasteltiin vain kahta tunnetta eli toivoa ja surua. Jatkossa on tarpeellista tarkastella ihmisten tunteita laajemmin, sillä esimerkiksi ilo ja rakkaus luontoa kohtaan vaikuttaa positiivisen luontosuhteen syntymiseen, mikä on yksi perusta ympäristömyönteiselle toiminnalla (Nisbet, Zelenski \& Murphy, 2009).

\section{Johtopäätökset}

Tutkimuksemme antaa viitteitä ratkaisukeskeisen ilmastonmuutoskasvatuksen (Ratinen ym., 2019) toteuttamisen ongelmista, joita täytyy pohtia kouluopetuksen suunnittelussa. Ratkaisukeskeiseen ilmastokasvatukseen vaikuttavat merkittävällä tavalla kasvatettavien taustat, asenteet, arvot, tunteet ja pohjatiedot. Oikeantasoisilla ja oppijoiden omaan arkeen liittyvillä tehtävillä voidaan kuitenkin rakentaa tutkivaan oppimiseen perustuvia vuorovaikutteisia kokonaisuuksia. Tästä huolimatta, kuten tämä tutki- 


\section{Ainedidaktiikka 4(3) (2020)}

mus osoitti, kaikki oppilaat eivät omasta mielestään koe opetusta opettavaisena tai vaikuttavana. Ratkaisukeskeinen ilmastokasvatus vaikuttaa oppilaiden tunteisiin. Tämä tutkimus jossain määrin paljasti, että opetuksella voidaan lisätä oppilaiden toivoa ilmastonmuutosta kohtaan. Alakoululaisten kohdalla erityisesti muiden lajien kärsiminen ilmastonmuutoksen vuoksi vaikutti aiheuttavan surua oppilaiden keskuudessa. Opetuksen järjestämisen näkökulmasta tämä tutkimus ei paljastanut, että lapsen arkea koskevien ilmastonmuutoksen hillintätoimien käsittelyllä olisi ollut negatiivista vaikutusta lapsen tunteisiin.

\section{Rajoitukset}

Tämän tutkimuksen tulokset johtuvat osittain myös käytetystä aineistonkeruumenetelmästä. Oppilaat eivät välttämättä osaa ilmaista oppimaansa kirjallisesti. Tutkimuksen tuloksissa on yhtymäkohtia Ahon ja Isoahon (2015) tutkimukseen. Heidän mukaansa suurimmalla osalla kuudes- ja yhdeksäsluokkalaisista on vaikeuksia kielellisessä ilmaisussa. Ongelma olisi ollut poistettavissa erilaisella tehtävänannolla, sillä Rättyän ja Kuljun (2018) mukaan tehtävänannoilla muotoiluineen on mahdollisuus laajentaa oppilaan käsitteellisen tiedon rakentumista. Tämän tutkimuksen aineisto paljastaa, että oppilaiden kokemuksien tutkimiseen ilmastokasvatuksen yhteydessä tulisi kehittää uusia tutkimusmenetelmiä. Luonnontieteiden ja kestävyyskasvatuksen pedagogiikassa on hyödynnetty keksintöpedagogiikkaa, jonka avulla on saatu rohkaisevia tuloksia (Juuti, 2020; Korhonen ym., 2014; Sinervo ym., 2020). Luovien ongelmaratkaisutehtävien dokumentointi ja oppimisprosessin paljastaminen auttaisi hahmottamaan myös ilmastonmuutokseen liittyviä tunnetiloja.

\section{Lähteet}

Aarnio-Linnanvuori, E. (2018). Ympäristö ylittää oppiainerajat: arvolatautuneisuus ja monialaisuus koulun ympäristöopetuksen haasteina. (Väitöskirja). Helsingin yliopisto. http://urn.fi/URN:ISBN:978-951-51-3836-1

Abrahams, I. \& Millar, R. (2008). Does practical work really work? A study of the effectiveness of practical work as a teaching and learning method in school science. International Journal of Science Education, 30(14), 1945-1969. https://doi.org/10.1080/09500690701749305

Aho, A. \& Isoaho, J. (2015). Äidinkielen kieliopin käsitteiden osaaminen. 6.-ja 9.-luokkalaisten oppilaiden subjektin ja predikaatin määritelmät, osaamiseen liittyvät ongelmat ja osaamisen taso. (Pro gradu -tutkielma). Tampereen yliopisto. http://urn.fi/URN:NBN:fi:uta-201505211469

Anderson, A. (2012). Climate change education for mitigation and adaptation. Journal of Education for Sustainable Development, 6(2), 191-206. https://doi.org/10.1177/0973408212475199

Bamberg, S., Rees, J. \& Seebauer, S. (2015). Collective climate action: Determinants of participation intention in community-based pro-environmental initiatives. Journal of Environmental Psychology, 43, 155-165. https://doi.org/10.1016/j.jenvp.2015.06.006

Banchi, H. \& Bell, R. (2008). The many levels of inquiry. Science and Children, 46(2), 26-29.

Branchetti, L., Cutler, M., Laherto, A., Levrini, O., Palmgren, E., Tasquier, G. \& Wilson, C. (2018). The I SEE project: An approach to futurize STEM education. Visions for Sustainability, 9, 10-26. https://doi.org/10.13135/2384-8677/2770

Burke, S., Sanson, A. \& Van Hoorn, J. (2018). The Psychological Effects of Climate Change on Children. Current Psychiatry Reports, 20(35). 


\section{Ainedidaktiikka 4(3) (2020)}

https://doi.org/10.1007/s11920-018-0896-9

Chapman, D. \& Lickel, B. \& Markowitz, E. M. (2017). Reassessing emotion in climate change communication. Nature Climate Change, 7(12), 850-852. https://doi.org/10.1038/s41558-017-0021-9

Degerman, L. (2016). Elever och klimatförändringen: En enkätundersökning bland finlandssvenska och svenska niondeklassare. (Väitöskirja). Åbo Akademi. http://urn.fi/URN:ISBN:978-951-765-841-6

Denzin, N. K. (2017). Sociological methods: A sourcebook. Abingdon: Routledge. https://doi.org/10.4324/9781315129945

Hicks, D. (2014). Educating for hope in troubled times: Climate change and the transition to a post-carbon future. London: Institute of Education Press.

Juuti, K. (2020). Kestävyysosaamisen karttuminen keksintöprojekteissa. Teoksessa T. Korhonen, \& K. Kangas (toim.), Keksimisen pedagogiikka (ss. 332-353). Jyväskylä: PS-kustannus.

Korhonen, T., Lavonen, J., Kukkonen, M., Sormunen, K. \& Juuti, K. (2014). The innovative school as an environment for the design of educational innovations. Teoksessa H. Niemi, J. Multisilta, L. Lipponen \& M. Vivitsou (toim.), Finnish Innovations and Technologies in Schools (ss. 97-113). Amsterdam: Sense Publishers. https://doi.org/10.1007/978-94-6209-749-0 9

Lambert, J. L., Lindgren, J. \& Bleicher, R. (2012). Assessing elementary science methods students' understanding about global climate change. International Journal of Science Education, 34(8), 1167-1187. https://doi.org/10.1080/09500693.2011.633938

Lombardi, D., Sinatra, G. M. \& Nussbaum, E. M. (2013). Plausibility reappraisals and shifts in middle school students' climate change conceptions. Learning and Instruction, 27, 50-62. https://doi.org/10.1016/j.learninstruc.2013.03.001

Lehtonen, J. \& Välimäki J. (2013). The environmental neurosis of modern man: The illusion of autonomy and the real dependence denied. Teoksessa S. Weintrobe (toim.), Engaging with climate change: Psychoanalytic perspectives (ss. 48-51). London: Routledge.

Lehtonen, A. \& Cantell, H. (2015). Ilmastokasvatus osaamisen ja vastuullisen kansalaisuuden perustana. Suomen ilmastopaneelin raportteja $1 / 2015$.

Li, C. J. \& Monroe, M. C. (2017). Exploring the essential psychological factors in fostering hope concerning climate change. Environmental Education Research, 25(6), 936-954.

van der Linden, S., Maibach, E. \& Leiserowitz, A. (2015). Improving Public Engagement With Climate Change: Five "Best Practice" Insights From Psychological Science. Perspectives on Psychological Science, 10(6), 758-763. https://doi.org/10.1177/1745691615598516

Monroe, M. C., Plate, R. R., Oxarart, A., Bowers, A. \& Chaves, W. A. (2019). Identifying effective climate change education strategies: A systematic review of the research. Environmental Education Research, 25(6), 791-812. https://doi.org/10.1080/13504622.2017.1360842

Muotka, A. \& Kinni, A. (2019). Luokanopen ilmasto-opas. (Luettu 20.8.2020 sivulta https://luokanopenilmasto-opas.fi/)

Nisbet, E. K., Zelenski, J. M. \& Murphy, S. A. (2009). The nature relatedness scale: Linking individuals' connection with nature to environmental concern and behavior. Environment and Behavior, 41(5), 715-740. https://doi.org/10.1177/0013916508318748

O’Brien, K., Selboe, E. \& Hayward, B. (2018). Exploring youth activism on climate change: Dutiful, disruptive, and dangerous dissent. Ecology and Society, 23(3), 42. https://doi.org/10.5751/ES-10287-230342

Ojala, M. (2012a). Hope and climate change: The importance of hope for environmental engagement among young people. Environmental Education Research, 18(5), 625-642. https://doi.org/10.1080/13504622.2011.637157

Ojala, M. (2012b). How do children cope with global climate change? Coping strategies, engagement, and well-being. Journal of Environmental Psychology, 32(3), 225 233. https://doi.org/10.1016/j.jenvp.2012.02.004

Ojala, M. (2015). Hope in the Face of Climate Change: Associations with Environmental Engagement and Student Perceptions of Teachers' Emotion Communication Style and Future Orientation. The Journal of Environmental Education, 46(3), 133-148. 


\section{Ainedidaktiikka 4(3) (2020)}

https://doi.org/10.1080/00958964.2015.1021662

Ojala, M., \& Bengtsson, H. (2019). Young People's Coping Strategies Concerning Climate Change: Relations to Perceived Communication with Parents and Friends and Proenvironmental Behavior. Environment and Behavior, 51(8), 907-935. https://doi.org/10.1177/0013916518763894

Pekrun, R. (2016). Academic emotions. Teoksessa R. Wentzel \& D. Miele (toim.), Handbook of Motivation at School (ss. 120-144). New York: Routledge.

Pihkala, P. (2017a). Päin helvettiä? Ympäristöahdistus ja toivo. Helsinki: Kirjapaja.

Pihkala, P. (2017b). Miksi ilmastonmuutoksesta on niin vaikea puhua? Monitieteellisiä näkökulmia. Tieteessä Tapahtuu, 35(1), 23-29. https://journal.fi/tt/article/view/60786

Pihkala, P. (2017c). Kuinka käsitellä maailman ongelmia? Traagisuus ja toivo ympäristökasvatuksessa. Ainedidaktiikka, 1(1), 2-15. https://doi.org/10.23988/ad.v1i1.65801

Pihkala, P. (2019a). Ilmastoahdistus ja sen kanssa eläminen. Raportti. Helsinki: MIELI Suomen mielenterveysseura ry. (Luettu 20.8.2020 sivulta: https://mieli.fi/fi/raportit/ilmastoahdistus-ja-sen-kanssa-eläminen)

Pihkala, P. (2019b). Ilmastokasvatus ja tunteet. (Luettu 20.8.2020 sivulta https://toivoajatoimintaa.fi/ilmastokasvatus-ja-tunteet/)

Ratinen, I. (2016). Primary student teachers' climate change conceptualization and implementation on inquiry-based and communicative science teaching: a design research. (Väitöskirja). Jyväskylän yliopisto. http://urn.fi/URN:ISBN:978-951-39-6667-6

Ratinen, I. \& Vettenranta, J. (2018). Oppilaiden ilmastonmuutososaamisen suhde heidän käsityksiinsä omasta ympäristötietoisuudesta ja -optimismista. Teoksessa J. Rautopuro \& K. Juuti (toim.), PISA pintaa syvemmältä: PISA 2015 Suomen pääraportti (ss. 153-173). Kasvatusalan tutkimuksia 77. Jyväskylä: Suomen Kasvatustieteellinen Seura.

Ratinen, I., Kinni, A., Muotka, A. \& Sarivaara, E. (2019). Kohti ratkaisukeskeistä ilmastokasvatusta. Suomen Ilmastopaneeli, Raportti 9/2019. https://www.ilmastopaneeli.fi/wp-content/uploads/2019/11/Ilmastokasvatusraportti final.pdf

Ratinen, I. \& Uusiautti, S. (2020). Finnish students' knowledge of climate change mitigation and its connection to hope. Sustainability, 12(6), 2181. https://doi.org/10.3390/su12062181

Reid, A. (2019). Climate change education and research: Possibilities and potentials versus problems and perils? Environmental Education Research, 25(6), 767-790. https://doi.org/10.1080/13504622.2019.1664075

Rättyä, K. \& Kulju, P. (2018). Kielitietoisuutta kielentämällä - kieliopin tehtävätyyppien kehittäminen. Ainedidaktiikka, 2(1), 59-74.https://doi.org/10.23988/ad.68750

Salmela-Aro, K. (2018). Motivaatio ja oppiminen kulkevat käsi kädessä. Teoksessa K. Salmela-Aro (toim.), Motivaatio ja oppiminen (ss. 9-22). Jyväskylä: PS-kustannus.

Saloranta, S. (2017). Koulun toimintakulttuurin merkitys kestävän kehityksen kasvatuksen toteuttamisessa perusopetuksen vuosiluokkien 1-6 kouluissa. (Väitöskirja). Helsingin yliopisto. http://urn.fi/URN:ISBN:978-951-51-3610-7

Sarajärvi, A. \& Tuomi, J. (2017). Laadullinen tutkimus ja sisällönanalyysi: Uudistettu laitos. Helsinki: Tammi.

Shepardson, D. P., Niyogi, D., Roychoudhury, A. \& Hirsch, A. (2012). Conceptualizing climate change in the context of a climate system: Implications for climate and environmental education. Environmental Education Research, 18(3), 323-352. https://doi.org/10.1080/13504622.2011.622839

Sinervo, S., Sormunen, K., Kangas, K., Hakkarainen, K., Lavonen, J., Juuti, K. \& Seitamaa-Hakkarainen, P. (2020). Elementary school pupils' co-inventions: Products and pupils' reflections on processes. International Journal of Technology and Design Education. https://doi.org/10.1007/s10798-020-09577-y

Sipari, P. (2016). Open ilmasto-opas. Luettavissa: https://openilmasto-opas.fi/

Strife, S. J. (2012). Children's Environmental Concerns: Expressing Ecophobia. Journal of Environmental Education, 43(1), 37-54. https://doi.org/10.1080/00958964.2011.602131 


\section{Ainedidaktiikka 4(3) (2020)}

Tolppanen, S., Aarnio-Linnanvuori, E., Cantell, H. \& Lehtonen, A. (2017). Pirullisen ongelman äärellä: kokonaisvaltaisen ilmastokasvatuksen malli. Kasvatus, 48(5), 456-468.

Uitto, A., Boeve-de Pauw, J. \& Saloranta, S. (2015). Participatory school experiences as facilitators for adolescents' ecological behavior. Journal of Environmental Psychology, 43, 55-65. https://doi.org/10.1016/j.jenvp.2015.05.007

Värri, V.-M. (2018). Kasvatus ekokriisin aikakaudella. Tampere: Vastapaino. 